ISSN 0258-7122

Bangladesh J. Agril. Res. 36(2) : 231-240, June 2011

\title{
YIELD RESPONSE AND NITROGEN USE EFFICIENCY OF WHEAT UNDER DIFFERENT DOSES AND SPLIT APPLICATION OF NITROGEN FERTILIZER
}

\author{
M. ATAUR RAHMAN ${ }^{1}$, M. A. Z. SARKER ${ }^{2}$, M. F. AMIN ${ }^{3}$ \\ A. H. S. JAHAN ${ }^{4}$ AND M. M. AKHTER ${ }^{5}$
}

\begin{abstract}
A field experiment was conducted at the central research farm of Bangladesh Agricultural Research Institute, Gazipur for two consecutive years to verify the yield response of wheat variety Prodip to different doses and split applications of $\mathrm{N}$ fertilizer to determine appropriate $\mathrm{N}$ dose and application method for increasing NUE and grain yield of wheat. The treatments comprised of 12 combinations of three doses of nitrogen $(80,100$, and $120 \mathrm{~kg} / \mathrm{ha}$ ) from urea, which were assigned in the main plots and four methods of $\mathrm{N}$ splitting viz., application of all $\mathrm{N}$ as basal; $2 / 3^{\text {rd }}$ basal plus $1 / 3^{\text {rd }}$ as top dress at crown root initiation (CR1) stage; $1 / 2$ basal plus $1 / 2$ as top dress at CR1 stage; and $1 / 3^{\text {rd }}$ basal with $1 / 3^{\text {rd }}$ as top dress at CR 1 plus $1 / 3^{\text {rd }}$ as top dress at 1 st node stage which were tested in the sub plots. Higher yield was achieved from N rate of 120 kgiha applied as three equal splits of one-third as basal during final land preparation, one-third as top dressing during CR1 and the rest one-third top dressing at first node stage. The yield advantage of wheat due to $\mathrm{N}$ treatments was attributed to higher thousand grain weight and spikes $/ \mathrm{m}^{2}$. Nitrogen content in wheat grain and straw was not affected significantly by different $\mathrm{N}$ treatment and their combinations, whereas plant $\mathrm{N}$ uptake was significantly influenced by $\mathrm{N}$ rate and $\mathrm{N}$ splitting and also due to the interaction of $\mathrm{N}$ rate and $\mathrm{N}$ splitting. Total $\mathrm{N}$ uptake was maximum under $\mathrm{N}$ rate of $120 \mathrm{~kg} / \mathrm{ha}$ applied as three equal splits as $1 / 3^{\text {rd }}$ basal with $1 / 3^{\text {rd }}$ as top dress at CR 1 plus $1 / 3^{\text {rd }}$ as top dress at $1^{\text {st }}$ node stage. Split applications of sub-optimal dose of $\mathrm{N}(80 \mathrm{~kg} / \mathrm{ha})$ resulted in negative gain in apparent NUE, but split applications, especially three split applications $\left(1 / 3^{\text {rd }}\right.$ basal, $1 / 3^{\text {rd }}$ at CR1, and $1 / 3^{\text {rd }}$ at $1^{\text {st }}$ node stage) of higher dose of $N$ (100 and 120 $\mathrm{kg} / \mathrm{ha}$ ) resulted in positive gain in apparent NUE.
\end{abstract}

Keywords: Wheat grain yield, nitrogen management, $\mathrm{N}$ uptake and NUE

\section{Introduction}

Nitrogen is the most important fertilizer element playing vital role in yield improvement of wheat and the element is frequently reported as deficient in agricultural soils of Bangladesh (Islam, 1990). Intensive irrigated farming of high-yielding varieties (HYV) of cereal crops and the removal of crop residue including the roots causing considerable decline in both organic matter and $\mathrm{N}$ content in agricultural soils of Bangladesh (Ali et al., 1997). Generally, the

${ }_{1,3 \& 4}$ Regional Wheat Research Centre (RWRC), Bangladesh Agricultural Research Institute (BARI), Gazipur, ${ }^{2 \& 5}$ Wheat Research Centre (WRC), BARI, Dinajpur, Bangladesh. 
agricultural soils are grossly $\mathrm{N}$ deficient and the crop responds to applied N. Crop response to applied $\mathrm{N}$ fertilizer depends on soil type, soil fertility, soil and crop management practices, crop variety, and also on the method of $\mathrm{N}$ application. In most crops, split application of $\mathrm{N}$ reported as beneficial rather than basal application of all $\mathrm{N}$ fertilizers. Three split application of $\mathrm{N}$ as top dress is a common practice for irrigated rice cultivation in Bangladesh, but in case of wheat, two-thirds of nitrogen fertilizer applied as basal during final land preparation and rest one-third applied as top dressing at crown root initiation (CR1) stage reported as most efficient in improving grain yield (Razzaque et al., 1980). The maximum use of $\mathrm{N}$ fertilizer as basal may cause less NUE thus three split applications of $\mathrm{N}$ viz., one- third as basal, one-third as top dressing during 20-25 days after sowing (DAS) and rest one-third as top dressing during 50-55 DAS are recommended for wheat according to fertilizer recommendation guide of Bangladesh Agricultural Research Council (BARC, 2005). Much works had been done to optimize N application rate (Malik, 1981; Sarker et al., 1997; Rahman et al., 2000; Rahman et al., 2002), method of placement and splitting of nitrogen (Razzaque et al., 1980; Prashad et al., 1987; Khan et al., 1990; OrtizMonasterio et al., 1994; Rahman et al., 2002). Fisher et al. (1993) reported that split application of $\mathrm{N}$ was effective in increasing wheat grain yield and especially grain protein was improved by the late application of N. Rahman et al. (2002) reported that $\mathrm{N}$ use efficiency of wheat was the maximum when nitrogen fertilizer was applied in three splits rather than two splits or applied as all basal in no-till condition However, still there are controversies in $\mathrm{N}$ fertilization to maximize wheat yield and that needed to elucidate for the benefit of wheat production. Therefore, the present study was undertaken to validate existing nitrogen application methods in order to optimize the dose of $\mathrm{N}$ fertilizer and recommend the most effective method of $\mathrm{N}$ application in wheat.

\section{Materials and Method}

The field experiment was conducted at the research farm of Bangladesh Agricultural Research Institute, Joydebpur, Gazipur $\left(23^{\circ} 59^{\prime} \mathrm{N}, 90^{\circ} 24^{\prime} \mathrm{E}\right.$, and $12 \mathrm{~m}$ above sea level) for two consecutive years of 2007-08 and 2008-09. The soil of the experimental field belongs to AEZ 28, which is characterized by flood free highland, fine in texture (silty clay loam), poor in organic matter $(1.1 \%)$, and total $\mathrm{N}(0.07 \%)$ content. The entire wheat growing period in 2008-09, was severely dry with no precipitation and also the relative humidity in this wheat season was lower compared to previous year (Fig. 1 and 2). Whereas, the seasonal rainfall during the cropping seasons of 2007-08 was $135 \mathrm{~mm}$ of which $83 \mathrm{~mm}$ occurred in the month of February during grain filling stage of wheat. 


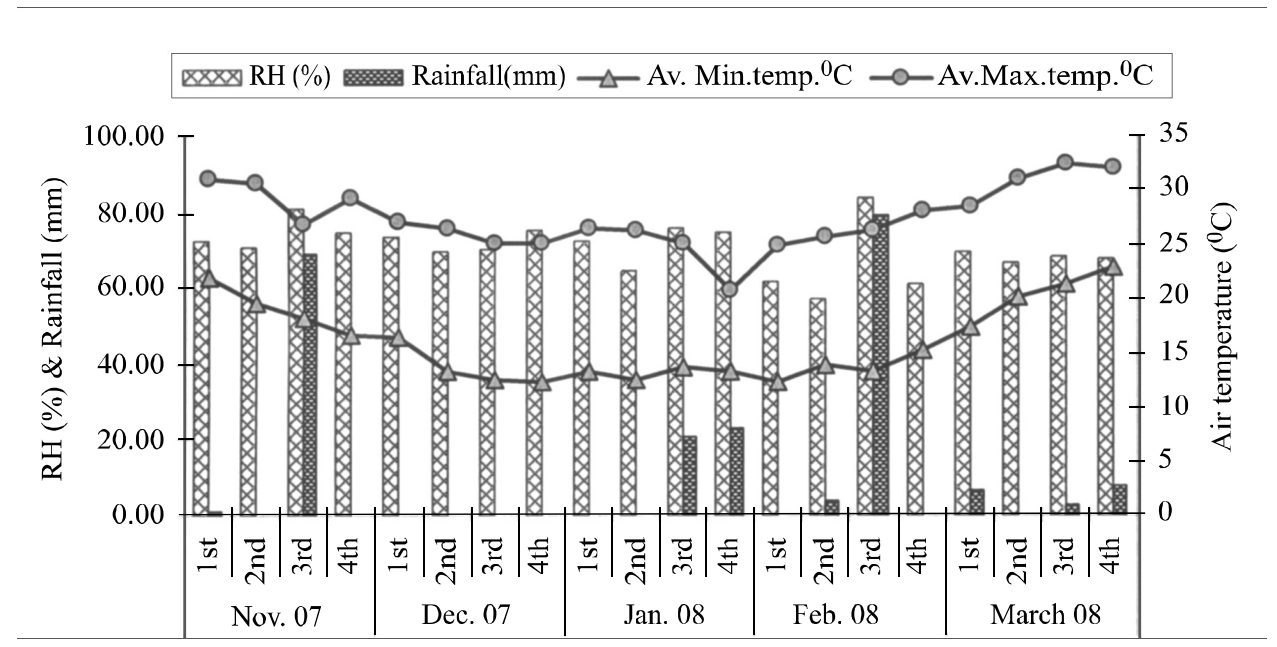

Fig. 1. Weekly average maximum and minimum air temperature, rainfall and relative humidity $(\mathrm{RH})$ during the cropping period of 2007-08.

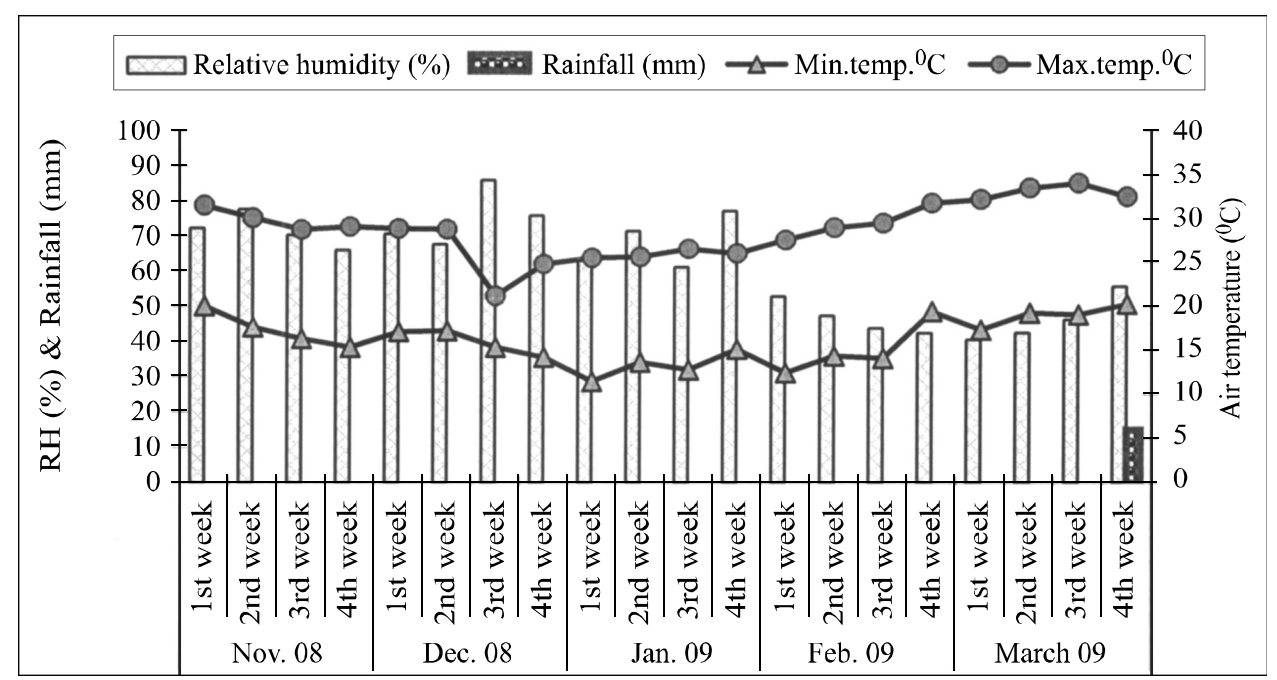

Fig. 2. Weekly average maximum and minimum air temperature, rainfall and relative humidity $(\mathrm{RH})$ during the cropping period of 2008-09.

The experiment was laid out in split plot design with three replications. Three rates of $\mathrm{N}(80,100$, and $120 \mathrm{~kg} / \mathrm{ha})$ from urea were assigned in the main plots and four methods of $\mathrm{N}$ splitting viz., application of all $\mathrm{N}$ as basal; $2 / 3^{\text {rd }}$ basal plus $1 / 3^{\text {rd }}$ as top dressing at crown root initiation (CRI) stage; $1 / 2$ basal plus $1 / 2$ as top dressing at CRI; and $1 / 3^{\text {rd }}$ basal with $1 / 3$ as top dressing at CR 1 plus $1 / 3^{\text {rd }}$ as top dressing at 1 st node stage were tested in the sub plots. Seeds of wheat variety Prodip were sown in $20 \mathrm{~cm}$ spaced line at the rate of $120 \mathrm{~kg} / \mathrm{ha}$ on $22^{\text {nd }}$ and $24^{\text {th }}$ 
November in 2007-08 and 2008-09, respectively. A blanket dose of fertilizers at the rates of $30 \mathrm{~kg} / \mathrm{ha} \mathrm{P}, 40 \mathrm{~kg} / \mathrm{ha} \mathrm{K}$, and $20 \mathrm{~kg} \mathrm{~S} / \mathrm{ha}$ were applied from triple super phosphate, muriate of potash, and gypsum, respectively. All fertilizers except urea were uniformly applied in the field during final land preparation, whereas $\mathrm{N}$ fertilizer was applied as per prescribed treatments. In 2008-09, the entire crop growth period was fairly dry thus the crop was irrigated uniformly to bring the soil moisture near to field capacity at 20, 40, and 65 days after sowing (DAS), whereas in 2007-08, third irrigation was not applied due to sufficient rainfall during that period. Weeds were controlled manually by hand weeding only at 10 days after first irrigation. Data on plant population, tillers per plant, plant height, spikes per $\mathrm{rn}^{2}$, spikelets per spike and grains per spike were noted duly. Matured plant samples were harvested from the central areas of $4 \mathrm{~m} \times 3 \mathrm{~m}$ of each sub-plot to determine grain yield and biomass. After threshing, the grains were sun dried and weighed. At the same time, grain moisture content was measured by using digital grain moisture meter (Model: TD-5, Ogawa Seiki Co. Ltd). Then plot-wise yield was converted to t/ha at $12 \%$ moisture content. In 2008-09, grain and straw samples were oven dried at $70^{\circ} \mathrm{C}$ for 72 hours and weighed to determine dry mass. Then grain and straw samples were ground by plant grinding mill and total $\mathrm{N}$ concentration in plant samples was determined by micro-Kjeldahl method nitrogen uptake was estimated by multiplying oven dry weight of the sample with $\mathrm{N}$ content in respective sample. Apparent agronomic nitrogen use efficiency (NUE) was calculated as the ratio of grain yield to the total $\mathrm{N}$ applied for the particular treatment. All data including yield and yield components were statistically analyzed and the means were tested by the least significant difference (LSD) at 5\% level of significance.

\section{Results and Discussion}

\section{a) Yield components}

Number of spikes per $\mathrm{rn}^{2}$, grains per spike, and 1000-grain weight (TGW) were considered as the most important yield components of wheat, which responded differently by individual and combined effect of $\mathrm{N}$ rates and $\mathrm{N}$ split applications (Table 1). Number of spikes per $\mathrm{m}^{2}$ was significantly influenced by the interaction of $\mathrm{N}$ rates and $\mathrm{N}$ split application in 2007-08. The maximum number of spikes per $\mathrm{m}^{2}$ was obtained from $120 \mathrm{~kg} \mathrm{~N}$ applied either as $\mathrm{N}_{1 / 3+1 / 3+1 / 3}$ or $\mathrm{N}_{1 / 2+1 / 2+0}$, and the same split applications of $100 \mathrm{~kg} \mathrm{~N}$ gave statistically similar result. Similar result of higher spikes per $\mathrm{m}^{2}$ due to three split applications of 120 or $100 \mathrm{~kg} \mathrm{~N}$ was observed in 2008-09. The higher number of spikes per $\mathrm{m}^{2}$ in response to aforementioned treatment combinations are in agreement with the finding of Rahman et al. (2002) who reported that $\mathrm{N}$ application have tremendous effect on tiller formation and survival of tillers. The individual and interaction effects of different $\mathrm{N}$ rates and $\mathrm{N}$ splitting on number of grains per spike were not statistically 
significant for both the years. Usually the number of grains per spike is determined at panicle primordial formation stage which strongly dependent on genetic factors rather than management factors (Schwarte et al., 2006). In severe boron deficient soil, partial or complete spike sterility might occur, thus in such a condition soil and crop management factors had significant effect on grains per spike (Rahman et al., 2005). The experimental soil was not boron deficient and spike sterility was not observed thus different $\mathrm{N}$ treatments gave statistically similar result on grains per spike. The main and interaction effects of $\mathrm{N}$ rates and $\mathrm{N}$-splitting on TGW were significant (Table 1). Three split application of $\mathrm{N}$ produced the maximum TGW of wheat in both the years. The result indicated that late application of $\mathrm{N}$ as top dressing was effective in improving kernel size of wheat. Due to the interactions, TGW was the highest under $\mathrm{N}$ rate of $120 \mathrm{~kg} / \mathrm{ha}$ applied as $\mathrm{N}_{1 / 3+1 / 3+1 / 3}$. Three split application of $\mathrm{N}\left(\mathrm{N}_{1 / 3+1 / 3+1 / 3}\right)$ at the rate of 100 and $120 \mathrm{~kg} / \mathrm{ha}$ resulted in statistically similar TGW. Again, N application at the rate of $100 \mathrm{~kg} / \mathrm{ha}$ in three equal splits produced significantly higher TGW than $\mathrm{N}$ rate of $120 \mathrm{~kg} / \mathrm{ha}$ applied as all basal in both the years. The result indicated that kernel size of wheat was more responsive to method and timing of $\mathrm{N}$ application rather than amount of $\mathrm{N}$ fertilization. The result also demonstrated that three split applications could save use of $\mathrm{N}$ at the rate of $20 \mathrm{~kg} / \mathrm{ha}$ without loosing the grain quality of kernel size. Ortiz et al. (1994) reported that late application of $\mathrm{N}$ improved grain $\mathrm{N}$ content and kernel size. Rahman et al. (2002) also found that three split applications of $\mathrm{N}$ was superior to all basal or two splitting in case of wheat variety Kanchan grown under no-till condition. Present study indicated that split application of $\mathrm{N}$ has the potentials to improve kernel size of wheat under conventional tillage condition too.

\section{b) Grain yield}

The individual effects of $\mathrm{N}$ rate and $\mathrm{N}$ split application and their interaction effects on grain yield of wheat were significant in most cases (Table 1). In general, grain yield of wheat was increased with the increasing $\mathrm{N}$ rate, though yields under 120 and $100 \mathrm{~kg} / \mathrm{ha} \mathrm{N}$ was statistically similar in both the years. The main effect of N splitting on grain yield of wheat was not significant in 2007-08, but it was significant in 2008-09 and three split applications of $\mathrm{N}$ produced maximum yield. Due to interactions, treatment combination of $\mathrm{N}$ rate of 120 $\mathrm{kg} / \mathrm{ha}$ applied as three split applications gave maximum yield in both the years. In general, grain yields were relatively low in 2008-09 than in 2007-08, which was due to unfavourable weather, especially higher temperature and drier environment in wheat growing season of 2008-09 compared to 2007-08 (Fig. 1 and 2). The mean yield of two years indicated that under the lower rate of $\mathrm{N}$ fertilizer $(80 \mathrm{~kg} / \mathrm{ha}), \mathrm{N}$ splitting had not any positive effect rather the application of all $\mathrm{N}$ as basal was superior (Fig. 3). In contrast, under the higher rate of $\mathrm{N}$ fertilizer (120 kg/ha), N splitting had significant positive effect and three split 
Table 1 Grain yield and yield components of wheat as influenced by $\mathbf{N}$ rate and $\mathrm{N}$ splitting methods for two consecutive years.

\begin{tabular}{|c|c|c|c|c|c|c|c|c|c|}
\hline \multicolumn{2}{|c|}{ Treatment } & \multicolumn{4}{|c|}{ 2007-08 } & \multicolumn{4}{|c|}{ 2008-09 } \\
\hline $\mathrm{N}$ rate & $\mathrm{N}$ splitting & Spikes $/ \mathrm{m}^{2}$ & Grains/spike & $\begin{array}{c}\text { 1000-grain } \\
\text { wt (g) }\end{array}$ & $\begin{array}{c}\text { Grain yield } \\
(\mathrm{t} / \mathrm{ha})\end{array}$ & Spikes $/ \mathrm{m}^{2}$ & Grains/spike & $\begin{array}{c}\text { 1000-grain } \\
\text { wt (g) }\end{array}$ & $\begin{array}{c}\text { Grain yield } \\
(\mathrm{t} / \mathrm{ha})\end{array}$ \\
\hline \multirow[t]{4}{*}{80} & $\mathrm{~N}_{1+0+0}$ & 292 & 35.7 & 44.3 & 3.18 & 216 & 43.1 & 43.0 & 3.21 \\
\hline & $\mathrm{N}_{2 / 3+1 / 3+0}$ & 285 & 33.3 & 48.5 & 3.22 & 214 & 40.2 & 45.5 & 3.12 \\
\hline & $\mathrm{N}_{1 / 2+1 / 2+0}$ & 289 & 36.4 & 50.1 & 2.96 & 217 & 41.2 & 46.8 & 2.95 \\
\hline & $\mathrm{N}_{1 / 3+1 / 3+1 / 3}$ & 277 & 36.2 & 50.9 & 2.74 & 219 & 37.6 & 47.4 & 2.97 \\
\hline \multirow[t]{4}{*}{100} & $\mathrm{~N}_{1+0+0}$ & 279 & 36.1 & 47.1 & 3.42 & 220 & 43.9 & 45.2 & 3.20 \\
\hline & $\mathrm{N}_{2 / 3+1 / 3+0}$ & 293 & 35.1 & 48.2 & 3.58 & 222 & 45.0 & 45.0 & 3.53 \\
\hline & $\mathrm{N}_{1 / 2+1 / 2+0}$ & 316 & 35.8 & 48.4 & 3.78 & 225 & 39.5 & 45.3 & 3.31 \\
\hline & $N_{1 / 3+1 / 3+1 / 3}$ & 318 & 36.6 & 51.5 & 3.66 & 234 & 43.0 & 48.0 & 3.58 \\
\hline \multirow[t]{4}{*}{120} & $\mathrm{~N}_{1+0+0}$ & 291 & 35.4 & 47.0 & 3.32 & 226 & 42.9 & 44.5 & 3.45 \\
\hline & $\mathrm{N}_{2 / 3+1 / 3+0}$ & 290 & 38.1 & 49.2 & 3.65 & 232 & 39.9 & 46.2 & 3.57 \\
\hline & $\mathrm{N}_{1 / 2+1 / 2+0}$ & 326 & 35.8 & 49.4 & 3.84 & 239 & 45.5 & 46.1 & 3.68 \\
\hline & $\mathrm{N}_{1 / 3+1 / 3+1 / 3}$ & 328. & 36.8 & 51.9 & 4.08 & 244 & 46.1 & 48.4 & 3.84 \\
\hline \multicolumn{10}{|c|}{ Mean of $\mathrm{N}$ rate } \\
\hline 80 & & 286 & 35.4 & 48.8 & 3.03 & 216 & 40.2 & 44.5 & 3.25 \\
\hline 100 & & 306 & 35.9 & 49.0 & 3.61 & 225 & 42.9 & 45.3 & 3.47 \\
\hline 120 & & 305 & 36.5 & 49.4 & 3.73 & 236 & 43.7 & 46.6 & 3.62 \\
\hline \multicolumn{10}{|c|}{ Mean of N splitting } \\
\hline & $\mathrm{N}_{1+0+0}$ & 287 & 35.7 & 45.6 & 3.31 & 221 & 43.5 & 44.1 & 3.26 \\
\hline & $\mathrm{N}_{2 / 3+1 / 3+0}$ & 289 & 35.5 & 48.7 & 3.48 & 223 & 42.0 & 45.6 & 3.44 \\
\hline & $\mathrm{N}_{1 / 2+1 / 2+0}$ & 311 & 35.9 & 49.3 & 3.59 & 228 & 41.7 & 46.0 & 3.31 \\
\hline & $\mathrm{N}_{1 / 3+1 / 3+1 / 3}$ & 312 & 36.5 & 51.4 & 3.47 & 232 & 41.8 & 47.4 & 3.53 \\
\hline \multirow{3}{*}{$\mathrm{LSD}(0.05)$} & $\mathrm{N}$ rate & 18 & Ns & Ns & 0.28 & 19 & Ns & Ns & 0.32 \\
\hline & Splitting & Ns & Ns & 3.1 & Ns & Ns & Ns & 3.2 & 0.26 \\
\hline & Interaction & 24.1 & Ns & 4.2 & 0.31 & Ns & Ns & 3.1 & 0.29 \\
\hline \multicolumn{10}{|c|}{$\begin{array}{l}\mathrm{N} \text { splitting: } \mathrm{N}_{1+4+0}=\text { All } \mathrm{N} \text { fertilizer applied as basal; } \mathrm{N}_{2 / 3+1 / 3+0}=\text { Two-thirds of } \mathrm{N} \text { fertilizer applied as basal and rest one-third of } \mathrm{N} \\
\text { fertilizer applied at CR1 stage as top dress; } \mathrm{N}_{1 / 2+1 / 2+0}=\text { Half of } \mathrm{N} \text { fertilizer applied as basal and rest half applied at CR1 stage as top dress; } \\
\mathrm{N}_{1 / 3+1 / 3+1 / 3}=\text { One-third of } \mathrm{N} \text { fertilizer applied as basal, one-third of } \mathrm{N} \text { fertilizer applied at CR1 stage and rest one-third of } \mathrm{N} \text { fertilizer } \\
\text { applied at first node stage as top dress. }\end{array}$} \\
\hline \multicolumn{10}{|c|}{ Ns = not significant. } \\
\hline
\end{tabular}


Table 2. $\mathbf{N}$ content, $\mathbf{N}$ uptake and $\mathbf{N}$ use efficiency of wheat as influenced by $\mathbf{N}$ rate and $\mathbf{N}$ splitting methods at Joydebpur in 2008-09.

\begin{tabular}{|c|c|c|c|c|c|c|c|}
\hline \multicolumn{2}{|c|}{ Treatments } & \multicolumn{2}{|c|}{ N Content (\%) } & \multicolumn{3}{|c|}{$\mathrm{N}$ uptake (kg/ha) } & \multirow{2}{*}{$\begin{array}{c}\text { N use efficiency (kg grain/ kg } \\
\text { N applied) }\end{array}$} \\
\hline $\mathrm{N}$ rate & N splitting & Grain & Straw & Grain & Straw & Total & \\
\hline \multirow[t]{4}{*}{80} & $\mathrm{~N}_{1+0+0}$ & 2.12 & 0.45 & 66.10 & 22.09 & 88.19 & 40.00 \\
\hline & $\mathrm{N}_{2 / 3+1 / 3+0}$ & 2.16 & 0.46 & 69.34 & 24.14 & 93.48 & 39.10 \\
\hline & $\mathrm{N}_{1 / 2+1 / 2+0}$ & 2.1 & 0.45 & 61.90 & 20.26 & 82.16 & 36.90 \\
\hline & $\mathrm{N}_{1 / 3+1 / 3+1 / 3}$ & 2.18 & 0.51 & 64.66 & 23.38 & 88.04 & 37.10 \\
\hline \multirow[t]{4}{*}{100} & $\mathrm{~N}_{1+0+0}$ & 2.15 & 0.44 & 74.13 & 23.59 & 97.72 & 32.20 \\
\hline & $\mathrm{N}_{2 / 3+1 / 3+0}$ & 2.21 & 0.47 & 78.92 & 26.64 & 105.60 & 35.30 \\
\hline & $\mathrm{N}_{1 / 2+1 / 2+0}$ & 2.24 & 0.43 & 82.45 & 24.85 & 107.30 & 33.10 \\
\hline & $\mathrm{N}_{1 / 3+1 / 3+1 / 3}$ & 2.24 & 0.48 & 84.67 & 28.10 & 112.80 & 35.80 \\
\hline \multirow[t]{4}{*}{120} & $\mathrm{~N}_{1+0+0}$ & 2.21 & 0.47 & 70.79 & 23.72 & 94.50 & 28.80 \\
\hline & $\mathrm{N}_{2 / 3+1 / 3+0}$ & 2.22 & 0.48 & 78.34 & 25.64 & 104.00 & 29.80 \\
\hline & $\mathrm{N}_{1 / 2+1 / 2+0}$ & 2.24 & 0.50 & 74.00 & 26.53 & 100.50 & 30.70 \\
\hline & $\mathrm{N}_{1 / 3+1 / 3+1 / 3}$ & 2.28 & 0.51 & 87.57 & 29.58 & 117.20 & 32.00 \\
\hline \multicolumn{8}{|c|}{ Mean of $\mathrm{N}$ rate } \\
\hline 80 & & 2.14 & 0.46 & 65.50 & 22.50 & 88.0 & 38.30 \\
\hline 100 & & 2.21 & 0.47 & 80.00 & 25.80 & 105.9 & 34.70 \\
\hline 120 & & 2.24 & 0.49 & 77.70 & 26.40 & 104.1 & 30.20 \\
\hline \multicolumn{8}{|c|}{ Mean of N splitting } \\
\hline & & 2.16 & 0.45 & 70.30 & 23.10 & 93.50 & 32.40 \\
\hline & & 2.20 & 0.47 & 75.50 & 25.50 & 101.0 & 34.40 \\
\hline & & 2.19 & 0.46 & 72.80 & 23.90 & 96.70 & 33.10 \\
\hline & & 2.23 & 0.50 & 78.97 & 27.00 & 106.0 & 35.80 \\
\hline \multirow[t]{3}{*}{$\overline{\mathrm{LSD}(0.05)}$} & & Ns & Ns & 7.87 & 3.45 & 11.22 & 4.10 \\
\hline & & Ns & Ns & 7.05 & 3.11 & 9.71 & Ns \\
\hline & & Ns & Ns & 6.16 & 2.42 & 8.20 & 4.70 \\
\hline
\end{tabular}

For footnote, see Table 1. 
applications gave higher yield over all basal or other split applications. Razzaque et al. (1980) reported that $\mathrm{N}$ rate of $100 \mathrm{~kg} / \mathrm{ha}$ applied as $2 / 3^{\text {rd }}$ basal and $1 / 3^{\text {rd }}$ top dress at CRI stage gave highest grain yield of wheat. On the contrary, Rahman et al. (1999) found that wheat yield was increased with $\mathrm{N}$ rate up to $160 \mathrm{~kg} / \mathrm{ha}$. As the soil fertility status varied frequently and the new wheat variety Prodip is more productive than older varieties thus the $\mathrm{N}$ requirement of Prodip might be higher than older varieties. In present study under the experimental soil conditions, $\mathrm{N}$ application of $120 \mathrm{~kg} / \mathrm{ha}$ applied as $1 / 3$ basal, $1 / 3$ top dress at CRI stage and $1 / 3^{\text {rd }}$ top dress at first node stage performed the maximum yield for both the years.

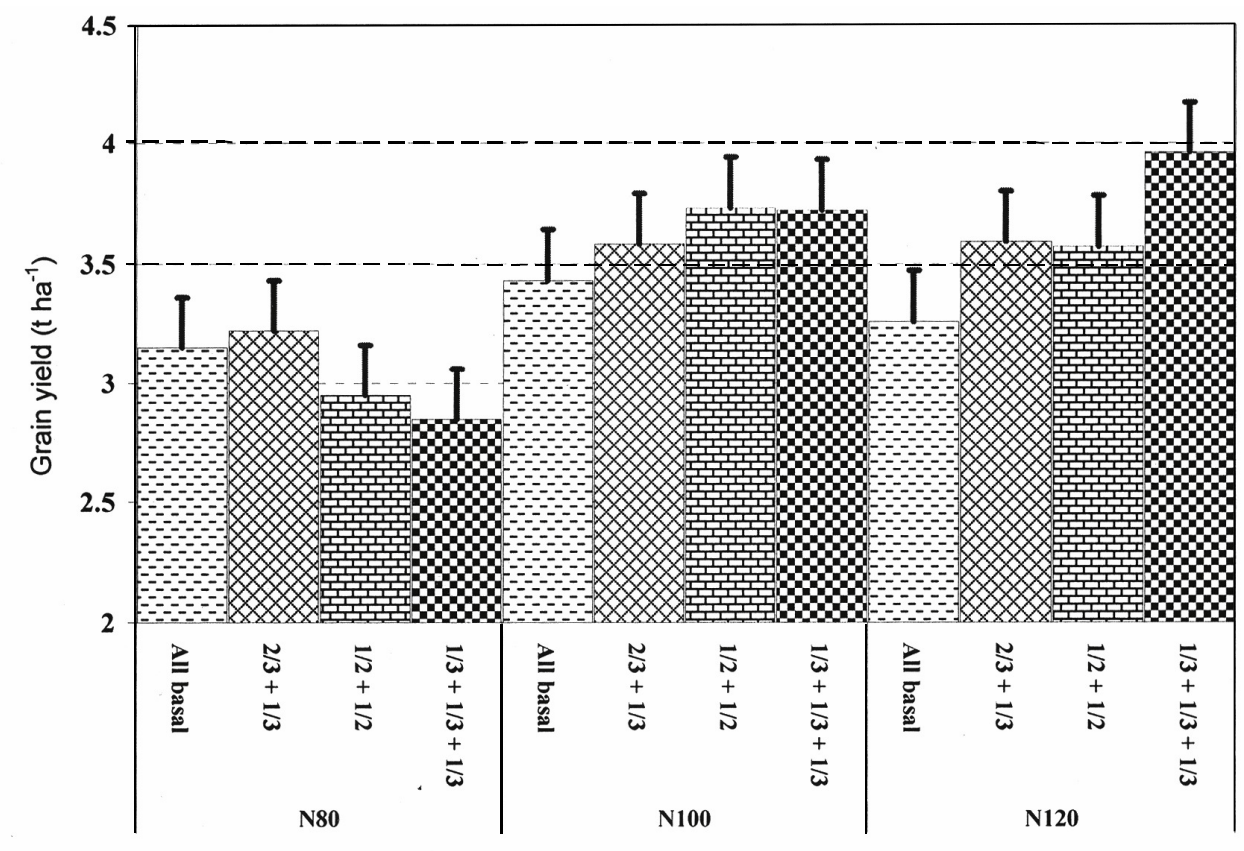

Fig. 3. Wheat grain yield (mean of two years) as influenced by the interaction of $\mathrm{N}$ rate and $\mathrm{N}$ splitting.

\section{C) $N$ uptake and apparent $N U E$}

The different rates of $\mathrm{N}$ application and its splitting created impact on $\mathrm{N}$ content in wheat grain and straw, but it was not statistically significant (Table 2). With increasing rate of $\mathrm{N}$ application from 80 to $120 \mathrm{~kg} / \mathrm{ha}$, the $\mathrm{N}$ content in grain increased from $2.14 \%$ to $2.24 \%$ and in straw, it rose from $0.46 \%$ to $0.49 \%$. Similarly, three split applications of $\mathrm{N}$ has led to increase grain $\mathrm{N}$ content from $2.16 \%$ (all basal) to $2.23 \%$ and straw $\mathrm{N}$ content from $0.45 \%$ to $0.50 \%$. The interaction effect of $\mathrm{N}$ rate and $\mathrm{N}$ splitting on $\mathrm{N}$ uptake by straw and grain as well 
as total $\mathrm{N}$ uptake by wheat plant were significant. Total $\mathrm{N}$ uptake by wheat plant was the highest $(117.2 \mathrm{~kg} / \mathrm{ha})$ under $\mathrm{N}$ rate of $120 \mathrm{~kg} / \mathrm{ha}$ applied in three equal splits followed by $\mathrm{N}$ rate of $100 \mathrm{~kg} / \mathrm{ha}$ applied in three equal splits. The result indicated that three equal split applications of $\mathrm{N}$ was effective in increasing $\mathrm{N}$ uptake of wheat. Though the treatment effect on $\mathrm{N}$ content in grain and straw was statistically similar, significantly higher $\mathrm{N}$ uptake was attributed to crop response of producing higher grain yield and biomass in response to treatments which ultimately contributed to higher total $\mathrm{N}$ uptake by wheat plant. Apparent nitrogen use efficiency (NUE) in terms of amount grain production per unit $\mathrm{N}$ applied significantly decreased with the increasing $\mathrm{N}$ rate but numerically increased with the increase in levels of $\mathrm{N}$ split applications (Table 2). Also the interaction effect of the two factors on NUE was also significant (Table 2). Under the sub-optimum rate of $\mathrm{N}(80 \mathrm{~kg} / \mathrm{ha}$ ), application of all basal gave the maximum NUE (40 kg grain/kg N) which was similar to two-thirds basal plus one-third top dressed at CR1, and NUE was not further improved due to increasing the levels of $\mathrm{N}$ splitting. In contrast, under the higher rate of N (120 or $100 \mathrm{~kg} / \mathrm{ha}$ ), NUE was the least when all $\mathrm{N}$ fertilizer was applied as basal and was improved with increasing the levels of $\mathrm{N}$ splitting. Generally, efficiency of $\mathrm{N}$ gradually decreased with increasing $\mathrm{N}$ rate (Rahman et al., 2000) and three split applications showed better efficiency of $\mathrm{N}$ with higher yield as compared to all basal or two split applications in no-till wheat (Rahman et al., 2002). The experimental result is also supported by Fisher et al. (1993) who reported that late split application of $\mathrm{N}$ increased grain $\mathrm{N}$ and thereby the grain protein content of wheat.

\section{Conclusion}

Two years' validation trial of $\mathrm{N}$ rate and $\mathrm{N}$ split applications indicated that both of the existing methods of nitrogen fertilizer splitting are effective in improving grain yield of wheat under different conditions. Under the lower level of $\mathrm{N}$ fertilizer ( $80 \mathrm{~kg} / \mathrm{ha}$ ), application of $\mathrm{N}$ as $2 / 3^{\text {rd }}$ basal and $1 / 3^{\text {rd }}$ top dressed at CRI stage gave higher yield. On the contrary, under higher level of $\mathrm{N}(120 \mathrm{~kg} / \mathrm{ha})$, grain yield and NUE was improved through three equal split applications as basal, top dress at CRI stage and first node stage of wheat. Considering the target of achieving higher yield, $\mathrm{N}$ rate of $120 \mathrm{~kg} / \mathrm{ha}$ might be recommended under the experimental soil condition of poor organic matter and low $\mathrm{N}$ content. The experimental result also suggests that nitrogen use efficiency was improved when higher dose of $\mathrm{N}(120 \mathrm{~kg} / \mathrm{ha})$ was applied in three splits rather then other applications. Thus for high yield goal, the recommendation of nitrogen at the rate of $120 \mathrm{~kg} / \mathrm{ha}$ applied as three equal three splits are the appropriate to improve wheat production in Bangladesh. 


\section{References}

Au, M. M., S. M. Shaheed, D. Kubota, T. Masunaga, and T. Wakatsuki.1997. Soil degradation during the period 1967-1995 in Bangladesh. I. Carbon and nitrogen. Soil Science and Plant Nutrition 43: 863-878.

BARC. 2005. Bangladesh Agricultural Research Council. Fertilizer Recommendation Guide, Bangladesh Agric. Res. Council, Farmgate, Dhaka 1215. pp. 259.

Fisher, R. A., G. N. Howe, and Z. Ibrahim. 1993. Irrigated spring wheat and timing and amount of nitrogen fertilizer. I. Grain yield and protein content. Field Crops Res. 33: 37-56

Islam, M. S. 1990. Nutrient status of some soils of Bangladesh. In: Proc. International symposium on paddy soil fertility. Bangladesh Agric. Res. Council, Dhaka, Bangladesh.

Khan, R. A., S. S. Tomar, N. S. Yadav, R. B. Sharma, P. S. Kushwah and M. P Jain. 1990. Response of wheat to irrigation and nitrogen. Indian Journal of Agronomy 35(4): 414-416.

Malik, C.V. S. 1981. Response of wheat varieties to different levels of nitrogen. Indian Journal of Agronomy 26(1): 93-96

Ortiz-Monasterio, 1. I., K. D. Sayre, J. Pena, and R. A. Fisher. 1994. Improving the nitrogen use efficiency of irrigated spring wheat in the Yaqui Valley of Mexico. Trans. 15th World Congr. Soil Sci. 5b: 348-349

Prasad, U. K., R. D. Pandey, T. N. Prasad, and A. K. Jah 1987. Effect of irrigation and nitrogen on wheat Ind. J. Agron. 32: 310-313.

Rahman, M. A., M. A. Sufian, M. Saifuzzaman, and J. Chikushi. 2002. Nitrogen management in rice-wheat alternating cropping system and wheat genotype identification preferable to surface seeding condition. J. Fac. Agr. Kyushu Univ., 46: 295-301.

Rahman, M. A., A. J. M. S. Karim, M. M. Haque and K. M. Saifuddin. 1999. Water use, yield and yield component of wheat under irrigation and nitrogen application in terrace soil of Bangladesh. Ann. Bangladesh. Agric. 9(2): 191-204.

Rahman, M. A., A. J. M. S. Karim, M. A. Shaheed and M. A. Samad. 2000. A study on the effect of irrigation and nitrigen fertilization on uptake and efficiency of nitrogen in wheat. Bangladesh. J. Agril. Res. 25(4): 578-583.

Razzaque, M. A., A. B. S. Hossain and M. A. Hossain. 1980. Effect of nitrogen rates and their time of application on HYV wheat. Bangladesh J. Agril. Res. 1: 33-40.

Sarker, M. A. Z., M. G. Miah, A. Hamid, J. Haider and A. Hashem. 1997. Effect of nitrogen level and duration of weed competition on weed biomass, yield and yield attributes of wheat. Ann. Bangladesh Agric. 7(1): 1-7.

Schwarte, A. J., L. R. Gibson, D. L. Karlen, P. M. Dixon, M. Lieman and J. L. Jannink. 2006. Planting date effects on winter triticale yield and yield components. Crop Sci. 46(3): 1218-1224. 